\title{
Lithostabilisation of Karal: Case of Maroua at the Far North Region of Cameroon
}

\author{
Mbessa $\mathrm{M}^{1 *}$ Deodonne $\mathrm{K}^{2}$, and Wansi LMW ${ }^{3}$ \\ ${ }^{1}$ Department of Civil Engineering, National Advanced School of Public Works, University of Yaounde, Cameroon \\ ${ }^{2}$ Inspectorate of Pedagogy for Industrial Education, Cameroon \\ ${ }^{3}$ University of Yaounde 1, Yaounde, Cameroon
}

Submission: September 17, 2019; Published: December 05, 2019

*Corresponding author: Mbessa M, Assistant Professor, Department of Civil Engineering, National Advanced School of Public Works, University of Yaounde 1, Yaounde, Cameroon

\begin{abstract}
The main objective of this study is to appreciate the swelling/shrinkage fluctuation of the Karal soil from Maroua city in the Far North region in Cameroon by adding sand at different content: $0,30,40,50,60$ and 70\%. The study passes through two types of tests named identification tests and characterization tests. The measuring of swelling/shrinkage amplitude was done using a comparator on a specific system conceived at the Laboratory of Building Materials of the National Advanced School of Public Works Yaounde. The results obtained lead to many conclusions:

i) the studied Karal soil is weak lift loamy clay belonging to A-7-6 class according to ASSHTO classification. This result has been already obtained in a previous study.

ii) the swelling/shrinkage phenomenon is observed when the water content starts decreasing and depends on the consistency of the material, because its highest sensitivity is observed when he passes from the hard state to the plastic state.

iii) the stabilizing effect of the sand starts at $40 \%$ content while the analysis of swelling/shrinkage fluctuation on the same mixtures at the optimal water content reveal that the smallest dimensional change is observed with $70 \%$ sand content mixture.
\end{abstract}

\section{Introduction}

Clayey soil (vertisols, planosols) are superficial layers less evolved and they are subject to volume variations as they are filled or not with water. Clayey soils are used in various domains and serve as building material, in the manufacturing of works of art and as support of buildings and roads. However, numerous problems of cracks met in buried pipes, pavements, buildings and roads result not only from an excessive loading of the base ground but also from several parameters which are mostly link to the characteristics of the base soil. In Cameroon, we meet clayey soil preferentially in the far north region of Cameroon [1]. In fact, this region is covered in large part by clay soil called "Karal lands" which have been proven to be one of the main causes of the swelling/shrinkage phenomenon [2-6]. Because of their instability, many constructions suffer from cracking due to their argillaceous nature, hence the need to stabilize them to be used in civil engineering. Karal has been the subject of several studies for stabilization [1,7-11] due to their predominance in this part of Cameroon. However, very few studies [12] address the dimensional variation aspect. The main interest of this work is to appreciate the dimensional changes of Karal when mixed with various sand contents $(0,30,40,50,60$ and $70 \%)$ in order to be use in civil engineering constructions.

\section{Materials and Method}

Several field works were realized and devoted to localizing monitoring sites and sampling. Laboratory tests included identification (Atterberg limits, particle size analysis and methylene blue) and characterization tests (sand equivalent, Proctor and measurement of dimensional change).

\section{Materials}

Hit points are located at two places; the first on the edge of the town of Maroua going towards Kaélé (Figure 1) and the second at salak near the interna-tional airport Maroua Salak (Figure 2). Materials were collected using parallel tubes and then coated with paraffin at their ends. This process allowed us to have an undisturbed sample that will give us in-formation on the type of soil in situ. Disturbed soil samples were collected using a shovel and a pick-axe. The samples were placed in bags 


\section{Civil Engineering Research Journal}

previously la-belled kw followed by numbers 1 and 2 indicating the site number. As regarding the sand (S1), it is tak-en from
River Sanaga because of the same structure and components as the one found in the northern part of Cameroon [1].

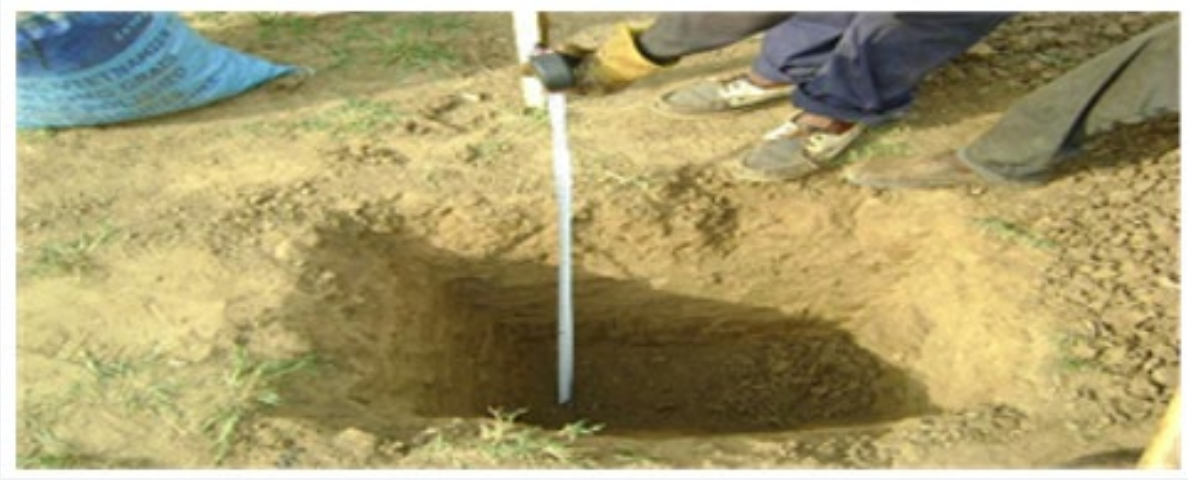

Figure 1: Monitoring Site $\mathrm{Kw}_{1}$.

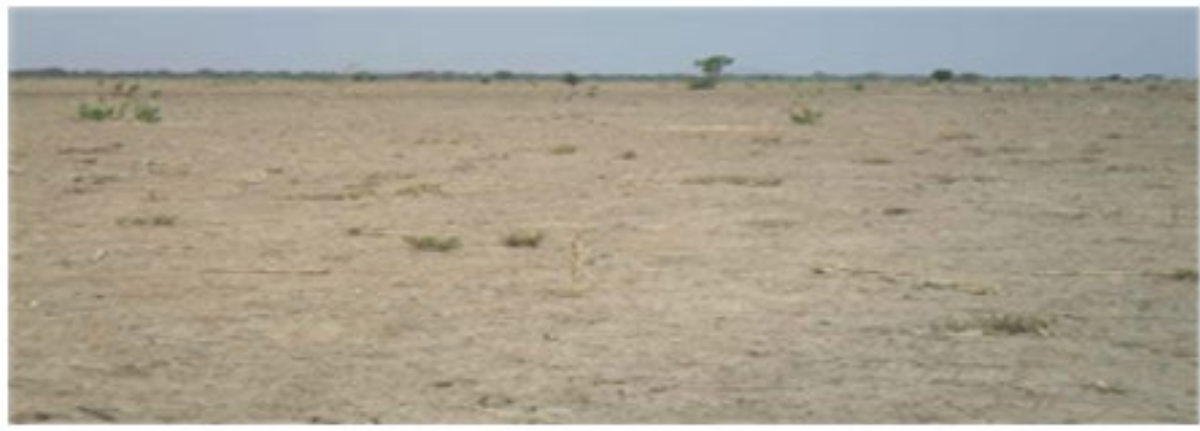

Figure 2: Monitoring Site $\mathrm{Kw}_{2}$.

\section{Laboratory work}

\section{Identification tests and classification}

Preliminary tests: Preliminary tests involve defining the nature of soils using basis human senses. They are indicated in Table 1 .

Table 1: Classification of Soil Through Preliminary Tests.

\begin{tabular}{|c|c|c|c|}
\hline \multirow{2}{*}{ Trials } & \multicolumn{2}{|c|}{ Nature of soil } \\
\cline { 2 - 4 } & Sandy & Silty & Clayey \\
\hline Sight & & No unpleasant sensation & Sticky in contact with the tongue \\
\hline Taste & Unpleasant sensation within the teeth & Averagely plastic & Plastic and sticky \\
\hline Touch & Rough & $/ /$ & Plastic and sticky \\
\hline Radiance & $/ /$ & & \\
\hline
\end{tabular}

Atterberg limits, grains size analysis and methylene bleu tests: The Atterberg limits, the particle size analysis and the methylene blue test are carried out respectively according to NF P94-051 [13], NF EN 933-1 [14] and NF P94-057 [15] and NF EN 933-9 [16].

\section{Characterization tests}

Sand equivalent test and the Proctor test: The Sand equivalent and proctor tests are realized following respectively NF EN 933-8 [17] and NF P 94-093 [18]. 


\section{Civil Engineering Research Journal}

Measurement of dimensional change: Measurements of dimensional change were carried out using the method proposed by the French norm NF P18-427 [15]. Measurements were performed on swelling clay sample both undisturbed and disturbed and on mixtures of the same clay with $0 \%, 30 \%, 40 \%, 50 \%, 60 \%$ and $70 \%$ of Sanaga sand.

\section{Results}

\section{Identification and classification of studied materials}

Preliminary characterization: Preliminary results on Karal and sand are presented in Table 2.

Table 2: Classification of Soil Through Preliminary Tests.

\begin{tabular}{|c|c|c|c|}
\hline Samples & Colour & Nature & Touch \\
\hline KW1 & Yellow & Clay & Sticky \\
\hline (S1) & Yellow & Sandy & Rough \\
\hline
\end{tabular}

Plasticity of materials: Results obtained from the Atterberg limit tests, as presented in Table 3, show that Karal is a high plas-ticity soil and is classified as Class A-7-6 according to the AASHTO classification. This material is not so advisable in road construction because of its fair to poor behaviour in road construction. It can be use unless it's ameliorated.

Table 3: Atterberg Limits Values.

\begin{tabular}{|c|c|c|c|}
\hline \multicolumn{1}{|c|}{ Samples } & $\mathbf{W}_{\mathbf{p}}$ & $\mathbf{W l}$ & $\mathbf{~ I P}$ \\
\hline Kw1 & 17,31 & 41,5 & 24,19 \\
\hline S1 & 14,8 & 20,46 & 5,66 \\
\hline
\end{tabular}

Grain size distribution: Table 4 present the different grains size content meanwhile Table 5 present rate of grain size in different mixture. The studied karal is silty clay. This nomenclature is specific to clay materials in the northern part of Cameroon [19]. The sand (S1) is of the gravel type as presented in Table 4 with $22 \%$ of gravel. Figures $3 \& 4$ show the particle size distribution of the karal sample and sand while Figure 5 shows the particle size curves of various mixtures.

Table 4: Rate of Grain Size (\%).

\begin{tabular}{|c|c|c|c|c|c|c|}
\hline \multirow{2}{*}{ Samples } & \multicolumn{4}{|c|}{ Rate of grain size (\%) } & \multirow{2}{*}{$\mathrm{C}_{\mathrm{u}}$} & \multirow{2}{*}{$\mathrm{C}_{\mathrm{c}}$} \\
\hline & Clay & Silt & Sand & Gravel & & \\
\hline KW1 & 56 & 40 & 2,16 & 1,84 & - & - \\
\hline S1 & 0 & 0 & 78 & 22 & 2,73 & 0,72 \\
\hline
\end{tabular}

Table 5: Summary of Grain Size Rate in Various Mixtures.

\begin{tabular}{|c|c|c|c|c|}
\hline \multicolumn{5}{|c|}{ Rate (\%) } \\
\hline Sand & Clay & Silts & Sand & Gravel \\
\hline 10 & 53,6 & 36 & 6,3 & 4,1 \\
\hline 20 & 40,6 & 21 & 31 & 7,4 \\
\hline 30 & 37 & 11 & 43 & 9 \\
\hline 40 & 31 & 9,3 & 49,3 & 10,4 \\
\hline
\end{tabular}

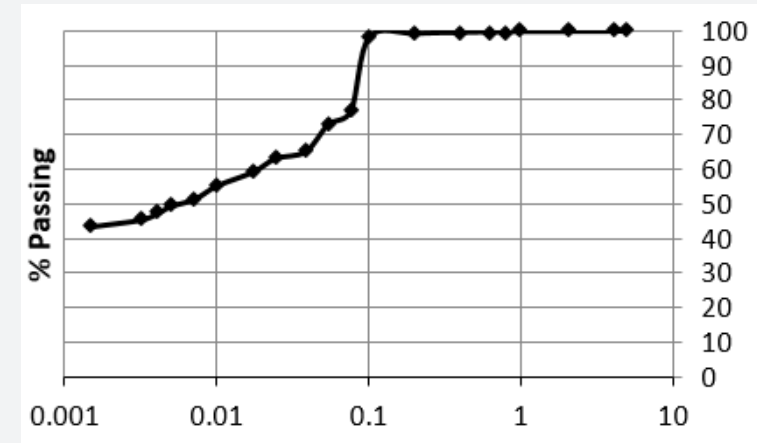

Figure 3: Size-Distribution Curve of the Karal Sample $\left(\mathrm{Kw}_{1}\right)$.

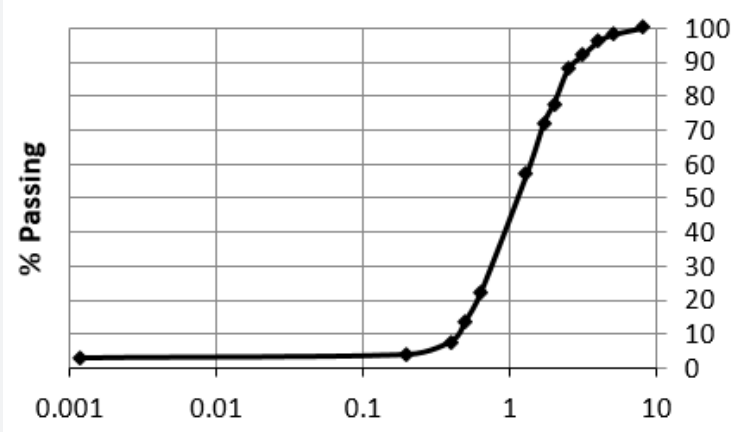

Figure 4: Granulometric Curve of the used Sand. 


\section{Civil Engineering Research Journal}

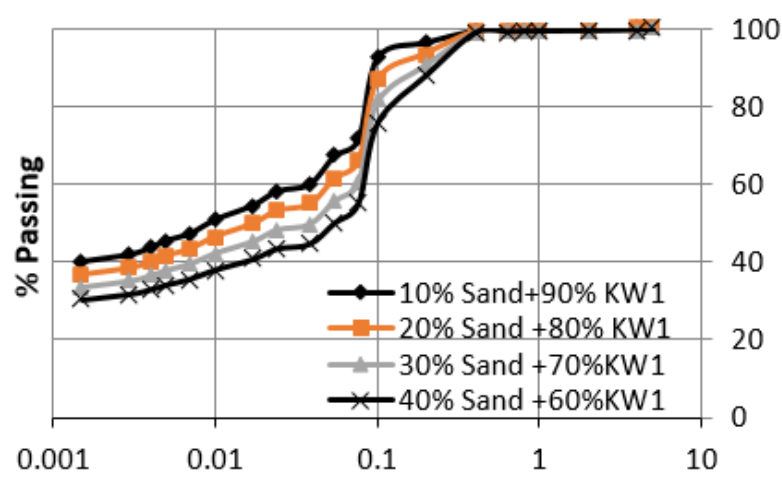

Figure 5: Granulometric Curves of different Mixtures (10\%, 20\%, 30\% and $40 \%$ of Sand Contain).

Value of Methylene blue: The value of methylene blue found is $11 \mathrm{~g} / 110 \mathrm{~g}$ soil, which qualifies Karal as a material at the threshold separating clay soils from very clay soils, with moderate swelling potential. In addition, the activity of clay fraction is estimated at 0.61 . This value is less than 0.5 obtained by Ekodeck [19]. According to the norm NF P 94-068 sand belongs to the group of inactive soils, this is due to the quartz nature of sands [20].

\section{Characterization of materials}

Sand Equivalent: Data used to calculate the sand equivalent show that the value of the visual sand equivalent is equal to $95.37 \%$ and $92.93 \%$ at the piston. These values de-scribe sand as a very clean one.

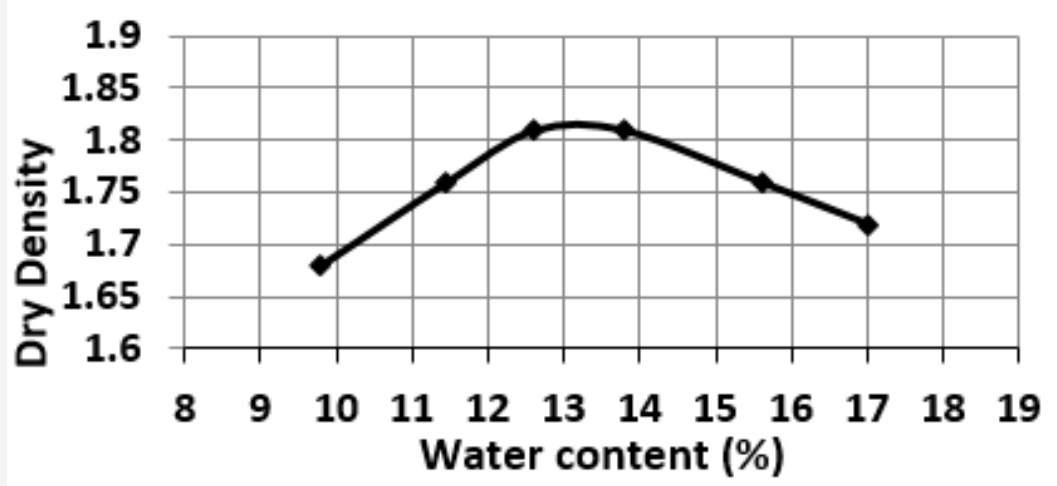

Figure 6: Proctor Curve of the Natural Karal.

Proctor: Results of the compaction test are recorded in Table 6 , while the dry density curve following specific water content is shown in Figure 6. This curve deducts the optimum water content and the optimum dry density value of $13.2 \%$ and 1.82 $\mathrm{g} / \mathrm{cm} 3$ for Kw1 respectively. The optimum proctor values found are different from those obtained by Simo [12]; this could be due to the amount of sand present in the material. The modified proctor test on different mixtures per-mitted to have curves shown in Figure 7 where dry density values are represented on $y$-axis and water content values on x-axis. The results are summarised in Table 7. The figure shows that the maximum dry density increases significantly with the percentage of sand as the optimal water content decreases. There-fore, the materials become less and less sensitive to water.

Table 6: Values of the Dry Density and the Water Content at the Optimal Proctor.

\begin{tabular}{|c|c|c|}
\hline \multirow{2}{*}{ Sample } & \multicolumn{2}{|c|}{ Optimal Proctor } \\
\hline \multirow{2}{*}{ Kw1 } & Dry density (max) & Optimal water content $\left(\boldsymbol{W}_{\text {opt }} \%\right)$ \\
\cline { 2 - 3 } & 1,819 & 13,20 \\
\hline
\end{tabular}

Table 7: Summary of Optimum Obtained for the Different Mixtures.

\begin{tabular}{|c|c|c|}
\hline Percentage of sand in $\mathbf{k w}_{\mathbf{1}}(\%)$ & Dry density $(\gamma d \boldsymbol{a}))$ & Optimal water content $\left(W_{\text {opt }}\right.$ in $\left.\%\right)$ \\
\hline 10 & 2.01 & 11.6 \\
\hline
\end{tabular}




\section{Civil Engineering Research Journal}

\begin{tabular}{|l|c|c|}
\hline 20 & 2.02 & 10.8 \\
\hline 30 & 2.029 & 10.6 \\
\hline 40 & 2.04 & 10.4 \\
\hline 50 & 2.05 & 9 \\
\hline 60 & 2.061 & 9.39 \\
\hline 70 & 2.11 & 9 \\
\hline
\end{tabular}
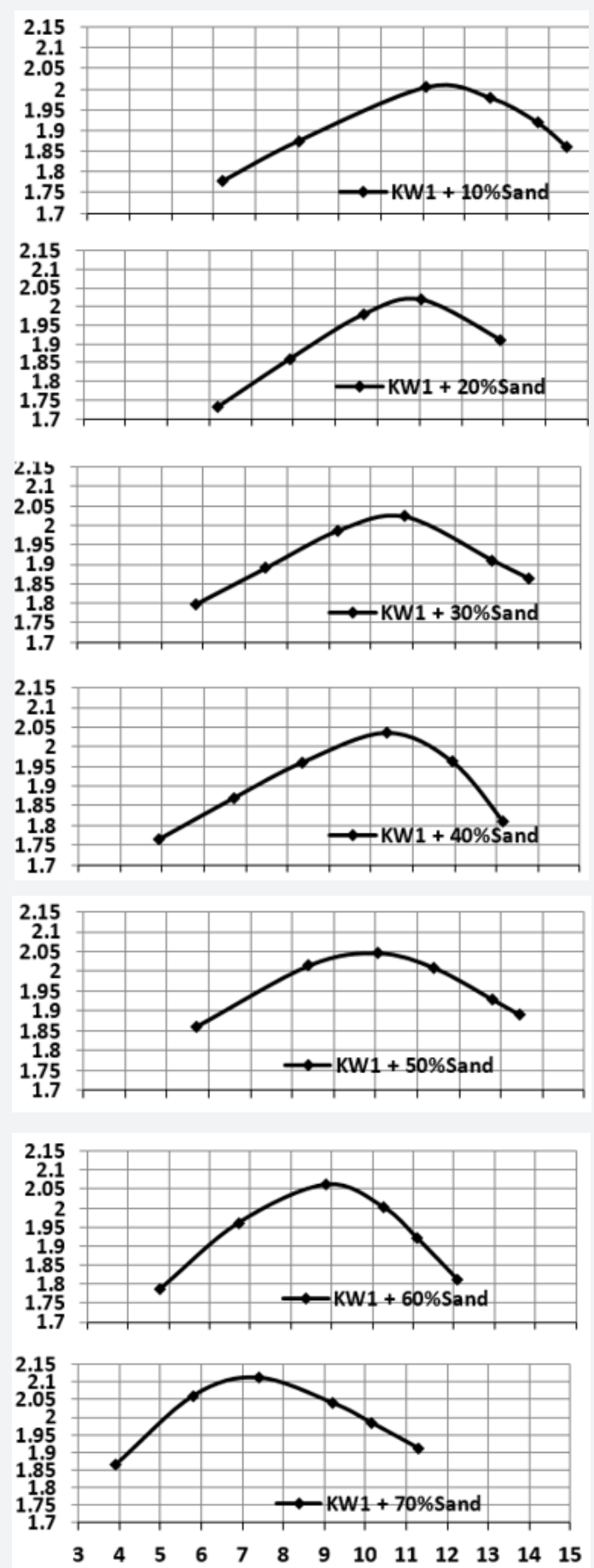

Figure 7: Proctor Curves of the Different Mixtures. 


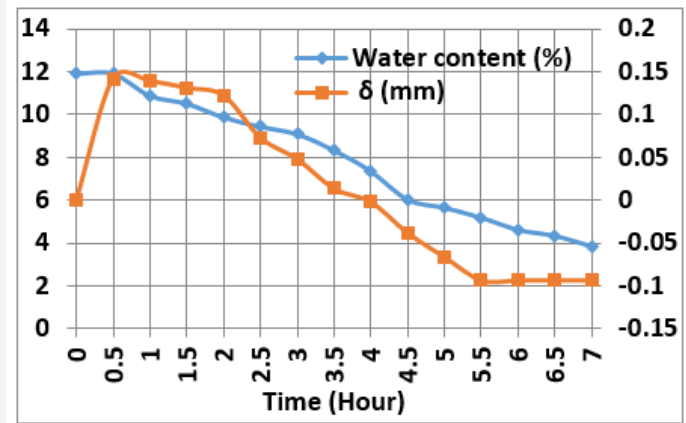

Figure 8: Dimensional Change of Natural Karal.
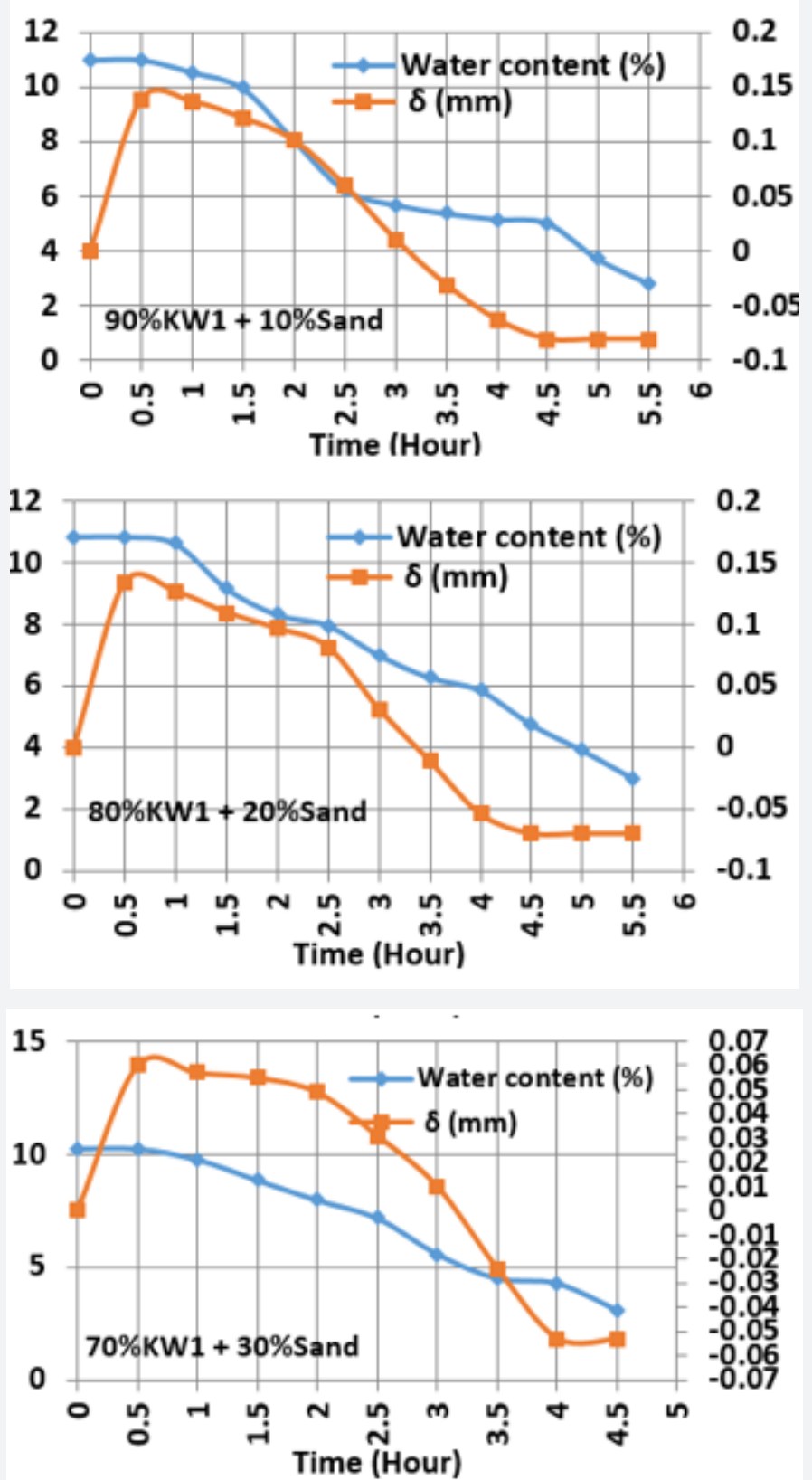


\section{Civil Engineering Research Journal}

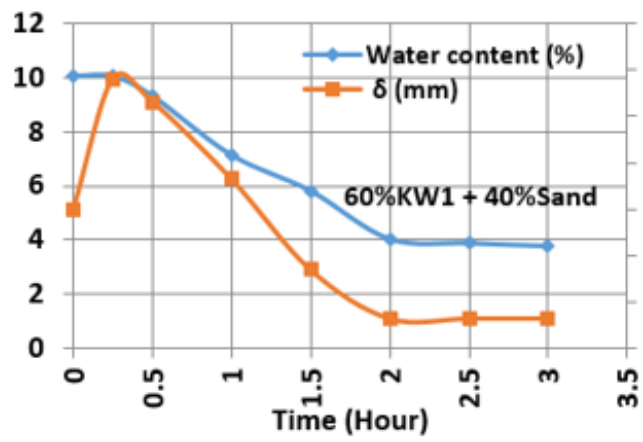

0.08

0.06

0.04

0.02

0

$-0.02$

$-0.04$ $-0.06$

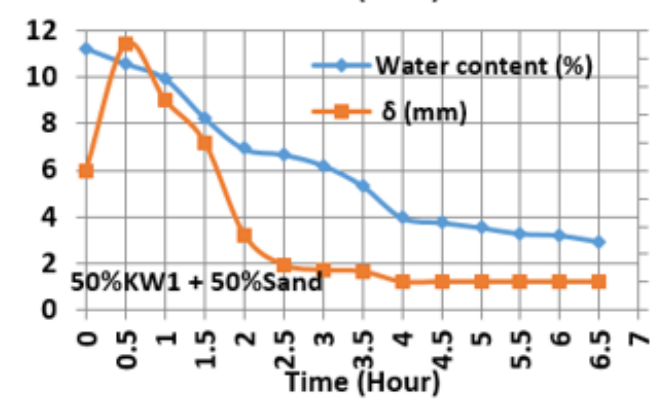

0.05

0.04

0.03

0.02

0.01

0

$-0.01$

$-0.02$

$-0.03$

-0.04
-0.05

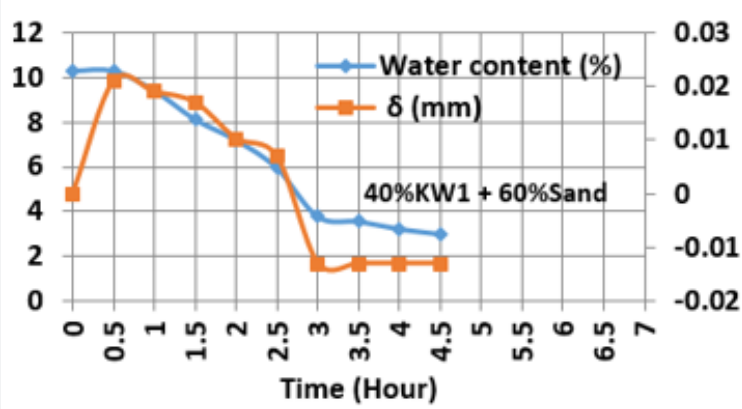

0.03

0.02

0.01

$-0.01$

$-0.02$

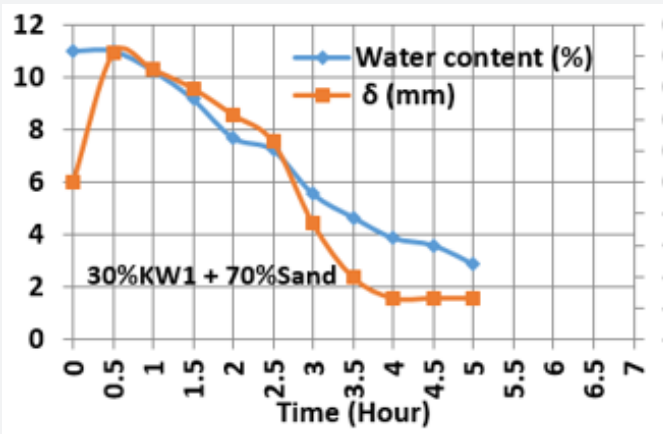

0.05

0.04

0.03

0.02

0.01

$-0.01$

$-0.02$

$-0.03$

$-0.04$

$-0.05$

Figure 9: Dimensional Change of Natural Karal.

Swelling-shrinkage: Laboratory results allowed the dimensional change of Karal to be represented by water content and time (Figure 8) on undisturbed or disturbed soil samples. The analysis of these results shows that Karal is a highly sensitive material same as Bana in their work published in 2016, it is observed just 30 minutes after the start of the test that the comparator needle reaches 14.2 . The shrinkage is progressively pronounced as the water content decreases and stabilizes after six (6) hours at the water content of 2.4. Regarding mixtures, the examination of the curves in Figure 9 shows that the amplitude of the swelling/shrinkage depends on the water content of the material. The phenomenon is more accentuated as the water content is high. The best results are observed for mixtures containing $70 \%$ of sand where the amplitude is then minimal as shown in Figure 10 and Table 8. 


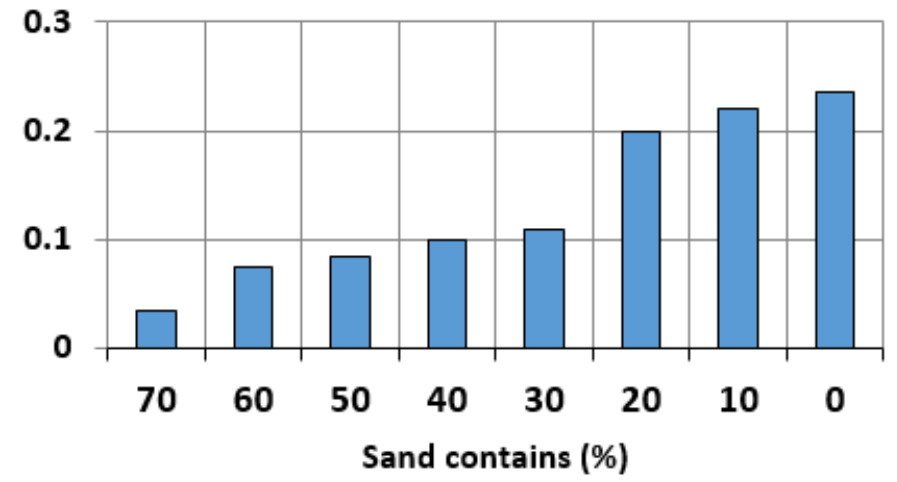

Figure 10: Amplitude Obtained from the Dimensional Change.

Table 8: Récapitulatif D’amplitude Pour Chaque Mélange.

\begin{tabular}{|c|c|c|c|}
\hline Ratio of Sand (\%) & Total swelling G (mm) & Shrinkage R (mm) & Amplitude $=\mathbf{G}+|\mathbf{R}|(\mathbf{m m})$ \\
\hline 0 & 0,142 & $-0,093$ & 0,235 \\
\hline 10 & 0,138 & $-0,081$ & 0,219 \\
\hline 20 & 0,133 & $-0,070$ & 0,203 \\
\hline 30 & 0,060 & $-0,053$ & 0,113 \\
\hline 40 & 0,056 & $-0,047$ & 0,103 \\
\hline 50 & 0,045 & $-0,040$ & 0,085 \\
\hline 70 & 0,041 & $-0,0367$ & 0,034 \\
\hline
\end{tabular}

\section{Conclusion}

The objective of this work was to study the dimensional change of karal in order to justify the relevance of its use in infrastructure works through mixtures of the latter with sand at various rate based on the results of previous work. Tests were conducted on natural Karal and sand-stabilized Karal at per-centages ranging from 10 to 70 , including identification tests such as particle size analysis, Atterberg limits, and characterization tests such as the modified Proctor test and comparator swelling/shrinkage measurement on Proctor Modified samples. The results of these tests show that the Karal studied is a low-lift, silty clay soil of class A-7-6 according to the ASHTO classification; the phenomenon of swell-ing-shrinkage occurs when the water content begins to decrease and depends on the state of consistency of Karal because its greater sensitivity is observed at the transition from solid to plastic; the effect of decreasing the swelling-shrinkage phenomenon by add-ing sand becomes perceptible from $40 \%$ sand. Swell-ing decreases as the proportion of sand increases. In the specific case, it was minimal for the value of $70 \%$ sand which is the highest percentage value used. The results obtained from this study are usable in road construction and in the building. However, the results obtained in this study do not allow us to understand all the causes of swelling/shrinkage.

\section{References}

1. Baana AM, Mamba M, Danwé R, Elime BA (2016) Effects on sand ion densities of swelling clay from the far north region of Cameroon, International Journal of Information Research and review 3(8): 2719-2724.

2. Thébé B (1987) Hydrodynamique de quelques sols du Nord Cameroun, bassins versants de MOUDA, contribution à l'étude des transferts d'échelles » Thèse de doctorat, uni-versité de Languedoc, ORSTOM fonds documentaire.

3. Humbel FX (1972) Initiation à la pédologie et aux sols ca-merounais, centre ORSTOM de Yaoundé, section pédolo-gie.

4. Lieunou GD, Sighomnou L, Sigha-Nkamdjou G, Mahe GE, Ekodeck F, Tchoual (2003). Système hydrologique du Yaéré(extrême Nard Cameroun), changements climatiques et actions anthropiques : conséquences sur les transferts superficiels. Proceedings of an international Symposium held at Montpellier April, IAHS Publ. P: 278-20003.

5. NF E 11-057. 2011. Mesure de la variation dimensionnelle à l'aide comparateur à cadran, $20 \mathrm{p}$.

6. Youdjari Djonkamla (2010) Caractérisation et simulation numérique $\mathrm{du}$ comportement volumétrique des sols argileux gonflants de N’Djamena, Mémoire de maitrise, Université Laval Québec, département du génie civil.

7. Hachichi A, Bourokba SA, Benaissa A, Fleureau JM, Hattab, M et al. (2009) Etude des phénomènes retrait-gonflement et stabilisation des sols gonflants de la région d'Oran. 19ième Congrès Français de Mécanique. Marseille, France 7: 24-28. 


\section{Civil Engineering Research Journal}

8. Louafi B, Derriche Z (2005) Effet d'un ajout de sable et l'influence de sa granularité sur les caractéristiques de gon-flement d'une argile pure. Géoline Lyon, France p: 7

9. Azzouz, FZ (2006) Contribution à l'étude de la stabilisation chimique de quelques argiles gonflantes de la région de Tlemcen. Mémoire Magister FacScide l'ingénieur, Univ.Abou Bekrbelkaid, Tlemcen Algérie, p: 179.

10. Nowamooz H (2007) Retrait/gonflement des sols argileux compactés et naturels. Thèse de Doctorat, Institut National Polytechnique de Lorraine, France P: 238.

11. Ngale EH, Tchangnwa FN, Touogam BT (2014) Karal clay in the Far North Cameroon: Study on Behavioural Floor Structures, International Journal of Engineering Research and Development 10(11): 29-40.

12. Simo DR (2013) Etude de la stabilisation du karal par ajout du sable dans la région de Maroua (extrême-nord Came-roun) mémoire, P: 145

13. NF P 94-051. 1993. Sols, reconnaissance et essais. Détermina-tion des Limites d'Atterberg. Limite de Liquidité à la cou-pelle-Limite de Plasticité au rouleau. AFNOR, 16p.

14. NF EN 933-1 (2012) Sols: reconnaissance et essais. Analyse granulométrique. Méthode par tamisage sous l'eau. AF-NOR, p: 16.
15. NF P 94-057 (1996) Sols: reconnaissance et essais. Analyse granulométrique. Méthode par sédimentation. AFNOR, p: 20.

16. NF EN 933-9 (2013) Sols, reconnaissance et essais. Mesure de la quantité d'absorption de bleu de méthylène d'un sol ou d'un matériau rocheux. Détermination de la valeur de bleu de méthylène d'un ou d'un matériau rocheux par l'essai de tâche. AFNOR p: 8.

17. NF EN 933-8. 2015. Granulats. Equivalent de sable. AFNOR, 8p.

18. NF P 94-093 (2014) Essai Proctor Normal -Essai Proctor Mo-difié. AFNOR, p: 17.

19. Ekodeck GE (1976) Contribution à l'étude de la nature et du comportement géotechnique des dépôts superficiels gon-flants du Nord Cameroun. Thèse de Doctorat 3ème cycle, Université de Grenoble I: 181.

20. Manjia M (2012) Cours de construction en terre, Ecole Natio-nale Supérieure Polytechnique de Yaoundé-Cameroun, p: 23.

21. Grove AT (1980) Geomorphic evolution of the Sahara and the Nile. In: Williams MAJ, Faure H (eds.), The Sahara and the Nile, Rotterdam, Balkema p: 21-35.

22. Mamba M, Nzengwa R, Tsomgné I (2001) Formulation d'un mortier de terre-ciment pour les murs mis en œuvre se-lon la technique du pies. Afrique science 07(2): 1-15.

\section{Your next submission with Juniper Publishers will reach you the below assets}

- Quality Editorial service

- Swift Peer Review

- Reprints availability

- E-prints Service

- Manuscript Podcast for convenient understanding

- Global attainment for your research

- Manuscript accessibility in different formats

( Pdf, E-pub, Full Text, Audio)

- Unceasing customer service

Track the below URL for one-step submission https://juniperpublishers.com/online-submission.php 